\title{
Brudd på menneskerettigheter i India
}

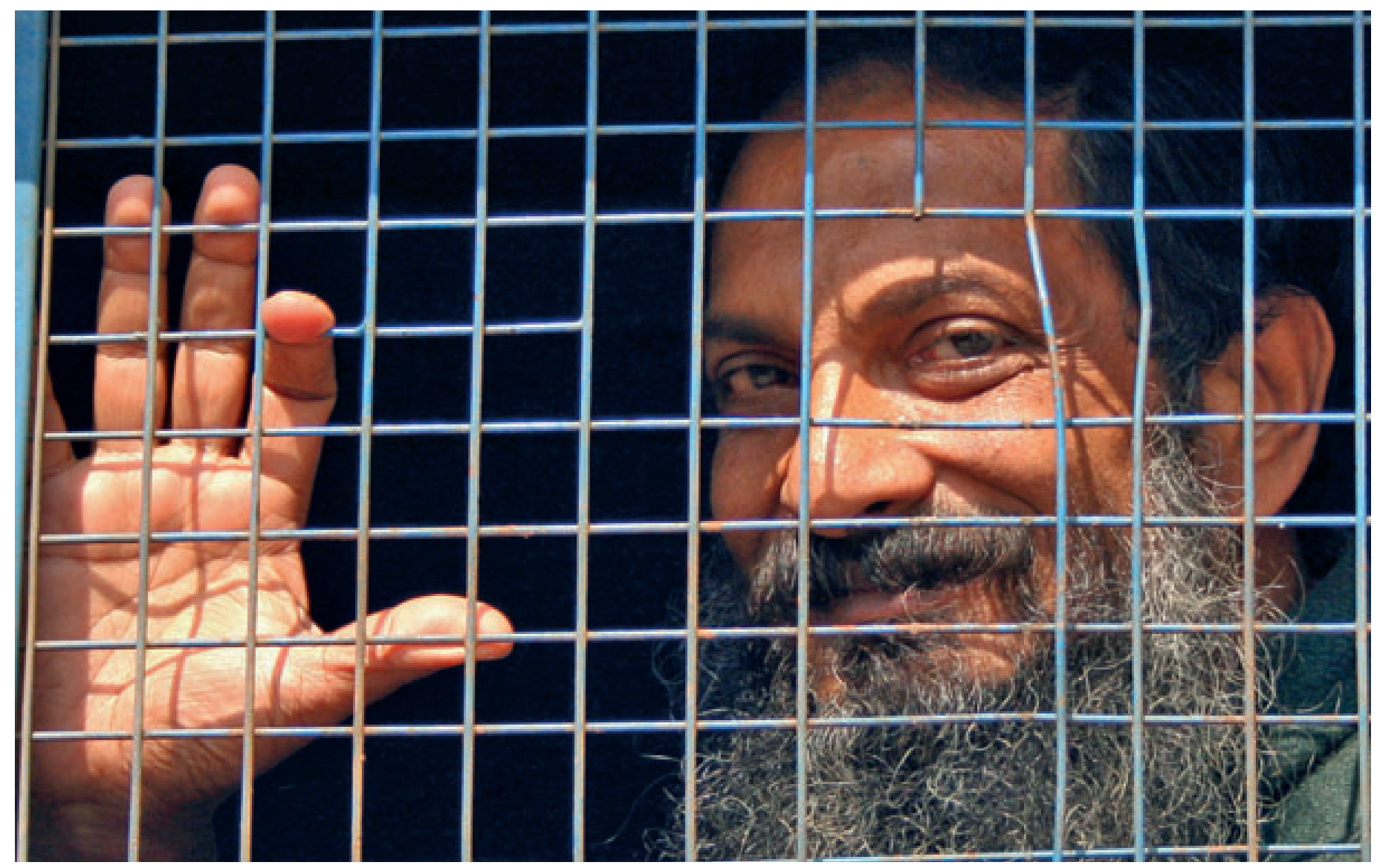

(c) Shailendra Pandey/Tehelka

24. desember 2010 ble barnelegen dr. Binayak Sen dømt til livsvarig fengsel etter å ha blitt anklaget for samarbeid med en maoistbevegelse som er aktiv i fattige delstater i India. Før det satt han fengslet i perioden 2007-09 mens det mange mener var en parodisk rettssak pågikk - fordi myndighetene mente han truet rikets sikkerhet (1). Ironisk nok er han dømt etter de samme lovene som de engelske koloniherrene brukte da de dømte Mahatma Gandhi for 60 år siden (2).

Menneskerettighetsorganisasjoner som Amnesty International, Human Right Watch og andre fordømmer dommen som politisk begrunnet (3). Også den indiske nobelprisvinneren i økonomi Amartya Sen og den amerikanske filosofen Noam Chomsky har kritisert dommen i sterke ordelag (3).

Dr. Sen har først og fremst vært en pioner i arbeidet med å bygge opp et bærekraftig helsetilbud i den fattige sentralindiske delstaten Chhattisgarh, hvor han har arbeidet i over 20 år som barnelege og menneskerettsaktivist. En betydelig del av befolkningen i delstaten er såkalte «adivasis» som regnes som urbefolkningen i området, og som er svært fattige. Sammenhengen mellom fattigdom og helse ble tidlig tydelig for Sen, som skjønte at en viktig premiss for helse i regionen var bedre levestandard. Derfor arbeidet han for å bedre levekårene til befolkningen, og han kritiserte myndighetene for å bidra til økt sosial skjevhet og uhelse gjennom å drive en politikk som prioriterer økonomisk profitt på bekostning av befolkningen.

I gruvebyen Dalli-Rajhara var Sen sentral i byggingen av et sykehus der alle kan bli behandlet til lavkostpris, og han har også bidratt til at gruvearbeidere og deres familier skal få bedre utdanning. Sykehuset har vært karakterisert som et mekka av personer som arbeider med å utvikle helsetilbudet på landsbygda i India. Sen var også visepresident i menneskerettsorganisasjonen People's Union for Civil Liberties.

Sens sak har vært beskrevet i flere lederartikler i BMJ (3) og i Lancet $(1,2)$. Grunnen til at han ble arrestert, er at han skal ha fungert som kurer for Narayan Sanyal, en fengslet leder av et forbudt kommunistparti. Sen har riktignok på frivillig basis hatt medisinsk tilsyn med Sanyal i fengselet, men det har alltid vært vakter til stede under hans besøk og Sen benekter da også å ha fungert som budbringer.
Det er beklagelig at dette skjer i dagens India. Sen har gjort en stor innsats for noen av landets fattigste innbyggere. EU stiller med observatører under ankesaken, som er berammet til 9. februar. Jeg oppfordrer Legeforeningen og Barnelegeforeningen i Norge til å engasjere seg for vår indiske kollega!

\section{Torstein Vik}

torstein.vik@ntnu.no

Institutt for laboratoriemedisin,

barne- og kvinnesykdommer

Norges teknisk-naturvitenskapelige universitet 7491 Trondheim

Oppgitte interessekonflikter: Ingen

Litteratur

. A right to a fair trial, a right to life. Lancet 2009; 373: 1146 .

2. Binayak Sen's conviction: a mockery of justice. Lancet 2011; 377: 98.

3. Zachariah P, Narayan R, Gaitonde R et al. The life imprisonment of Dr. Binayak Sen. BMJ 2011; 342 : d262.

Mottatt 23.1. 2011, godkjent 30.1. 2011. Medisinsk redaktør Anne Kveim Lie. 